\title{
Biochemical and physiological changes of Tabebuia roseoalba (Ridl.) Sandwith (Bignoniaceae) seeds under storage ${ }^{1}$
}

\author{
Leticia Caravita Abbade ${ }^{2 *}$, Massanori Takaki ${ }^{3}$
}

\begin{abstract}
Tabebuia roseoalba (Ridl.) Sandwith is a Brazilian forest species, with great use in landscaping and reforestation, occurring mainly in the semi-deciduous forest. Seeds are small, lightweight, winged and wind-dispersed. The objective of this study was to verify the physiological quality and biochemical changes in T. roseoalba seeds during 24-month storage. The following were assessed: germination, emergence, seedling length and seedling dry weight, content of lipids, proteins and phenolic compounds, and enzyme activity. Loss of seed quality during storage was evidenced by reduced germination and emergence, shorter seedling length and lower seedling dry weight, decreased content of lipids and proteins, decreased peroxidase and catalase activity, and increased phenolic compound content and polyphenol oxidase activity. Seeds should be stored and used within six months after collection.
\end{abstract}

Index terms: germination, emergence, lipids, peroxidase, polyphenol oxidase, catalase.

\section{Alterações bioquímicas e fisiológicas das sementes de Tabebuia roseoalba (Ridl.) Sandwith (Bignoniaceae) submetidas ao armazenamento}

\begin{abstract}
RESUMO - O ipê-branco (Tabebuia roseoalba (Ridl.) Sandwith) é uma espécie florestal brasileira, com grande utilidade em paisagismo e reflorestamento, ocorrendo principalmente na floresta semidecídua. Suas sementes são pequenas, leves, aladas e dispersadas pelo vento. O objetivo neste trabalho foi verificar a qualidade fisiológica e as alterações bioquímicas das sementes de ipêbranco durante o armazenamento por 24 meses. Avaliou-se a germinação, emergência, comprimento e massa seca das plântulas, o conteúdo de lipídios, proteínas, a atividade enzimática e compostos fenólicos. A perda de qualidade fisiológica das sementes durante o armazenamento foi evidenciada pela redução da germinação, da emergência, do menor comprimento e massa seca das plântulas, da diminuição dos níveis de lipídeos e proteínas, da atividade da peroxidase e catalase e do aumento de compostos fenólicos e da atividade da polifenoloxidase. As sementes devem ser armazenadas e utilizadas até seis meses após a coleta.
\end{abstract}

Termos para indexação: germinação, emergência, lipídeos, peroxidase, polifenoloxidase, catalase.

\section{Introduction}

The white ipe (Tabebuia roseoalba (Ridl.) Sandwith) belongs to the family Bignoniaceae and occurs in several regions of Brazil. It has large commercial, medicinal and ornamental value, with widespread use in urban forestry and plant recovery of degraded areas (Pott and Pott, 1994; Lorenzi, 2009). Its seeds are small and winged, and they are produced in large quantities with short viability period under natural conditions (Lorenzi, 2009).

Tabebuia seeds are currently classified as orthodox and, thus, should remain viable after dried to water content below $5 \%$ and stored at low temperatures for long periods. However,

${ }^{1}$ Submitted on 01/27/2014. Accepted for publication on 02/18/2014.

${ }^{2}$ Universidade Federal de Uberlândia, Instituto de Biologia, 38400-902 Uberlândia, MG, Brasil.

${ }^{3}$ Instituto de Biociências, UNESP - Univ Estadual Paulista, Campus de Rio seed germination for T. roseoalba is significantly reduced after 60-day storage in the laboratory (Carvalho et al., 2006) and seed viability decreases after 180 days when the seeds are packed in cans and kept in a refrigerator (Borba Filho and Perez, 2009). Loss of viability during storage may be due to a small amount of seed reserves, which is rapidly consumed during germination (Abbade and Takaki, 2012).

Knowledge of the behavior of forest seeds under different storage conditions is extremely important for the rational management of the species, and it also allows increased availability period for seeds with high germination and vigor so that new seedlings are continuously produced with satisfactory quality (Guedes et al., 2012).

Claro, Departamento de Botânica, Laboratório de Fotomorfogênese, CaixaPostal 199, 13506-900 - Rio Claro, SP, Brasil.

*Corresponding author < leticiabbade@yahoo.com.br> 
The first step of seed deterioration is the degradation of cell membrane systems (Delouche and Baskin, 1973). The exudation of cell constituents is inversely related to vigor, based on three factors: it reflects the loss of membrane integrity, it is the resulting loss of compartmentalization of cell constituents, and it is an excellent substrate for the growth of microorganisms, thus accelerating seed deterioration (Nascimento et al., 2010).

During the process of deterioration, enzyme activity is reduced; as a result, the functionality of the membranes is changed, and lipid peroxidation, enzyme inactivation and nucleic acid degradation occur (Greggains et al., 2000). According to Berjak (2006), the reduction in the activity of free radical scavenger enzymes increases the sensitivity of seeds to oxidative stress. Superoxide dismutase, catalase and peroxidase are enzymes that scavenge free radicals and peroxides, as well as malate dehydrogenase, acid phosphatase and glutamate dehydrogenase, which are indicative of deterioration, as they are involved in cellular metabolism (Taveira et al., 2012). Thus, information on the activity of certain enzymes, added to information on the degradation of reserves and/or biosynthesis of new tissues, may be used in studies on seed deterioration (Santos et al., 2005).

In Pterogyne nitens seeds, physiological changes as well as changes in catalase activity are associated with decreased physiological quality of artificially aged seeds (Ataide et al., 2012). Similarly, in Melanoxylon brauna seeds, significant decreases were observed in the activity of the enzyme catalase with increased seed deterioration (Corte et al., 2010). For Triticum aestivum, the reduction of seed vigor during artificial aging was associated with decreased activity of catalase and superoxide dismutase, which also result from seed deterioration (Lehner et al., 2008).

For storage of forest seeds, the genus Tabebuia in paticular, there are few published studies on seed longevity during storage. Thus, there is a clear need to deepen knowledge of the physiology of White ipe seeds during storage. Based on this, the objective of this study was to identify the biochemical and physiological changes in seeds of Tabebuia roseoalba (Ridl.) Sandwith (Bignoniaceae) under storage.

\section{Material and Methods}

The experiment was conducted at the Laboratory of Plant Photomorphogenesis in the Department of Botany of Universidade Estadual Paulista (UNESP), in Rio Claro, state of São Paulo, Brazil. The seeds of Tabebuia roseoalba were collected in September and October 2009, when the fruits split open at maturity, from trees located on the campus of
UNESP in Rio Claro. Freshly collected seeds and seeds stored for up to 24 months were kept in airtight containers at $5{ }^{\circ} \mathrm{C}$ in a BOD incubator at $5{ }^{\circ} \mathrm{C}$ (Borba Filho and Perez, 2009). The samples were assessed every six months for 24 months. At the time of storage, seed water content was $10 \%$ as determined by drying the seeds at $105 \pm 3{ }^{\circ} \mathrm{C}$ for 24 hours, according to Brasil (2009). Seeds were evaluated for their physiological quality, and chemical analysis and assessment of enzyme activity by the tests described below.

\section{Physiological assessments}

Germination - was conducted according to Stockman et al. (2007) in an incubator at $30{ }^{\circ} \mathrm{C}$ under continuous white light. Four replicates of 25 seeds were used for each treatment. The seeds were germinated in gerbox with filter paper moistened with distilled water. The assessments were performed daily from day 2 until day 15 after the start of the test, and the results were expressed as mean percentage of normal seedlings.

Emergence - performed with four replicates of 25 seeds, sown at a spacing of $5 \mathrm{~cm}$ and a depth of $1 \mathrm{~cm}$ in sand substrate and subsoil (1:1) in a greenhouse with controlled irrigation (Abbade et al., 2010). Counts of emerged seedlings were assessed at 15 days after sowing (Stockman et al., 2007), and the results were expressed in mean percentage of normal seedlings.

Seedling length and seedling dry weight - 25 seeds were sown between moistened filter paper sheets, and they remained in an incubator at constant temperature of $25^{\circ} \mathrm{C}$ until the time of assessment, at 30 days after sowing. A graduated ruler was used to measure the length of the shoot and root system (primary root). In each treatment, the average lengths of the seedlings were calculated, and the results were expressed in cm.seedling ${ }^{-1}$ according to Nakagawa (1999). After the seedlings were measured, they were taken to an incubator at $50{ }^{\circ} \mathrm{C}$ for 72 hours, and after drying, they were weighed. The results were expressed in mean dry mass (mg.seedling $\left.{ }^{-1}\right)$.

\section{Chemical Assessments}

Lipid content - the seeds were ground in a cutting mill and subsequently macerated with mortar and pestle in a chloroformmethanol-distilled water solution (1:2:1 v: v) according to the method of Bligh and Dyer (1959). Four replicates of $1 \mathrm{~g}$ of seeds were used. The analyses were performed in triplicate and the results were expressed as mean and standard deviation of the determinations. Total lipid content was determined by the gravimetric method, calculating the difference between the initial and final weights of the samples. The results were expressed in percentage of lipids.

Protein content - the seeds were soaked with the mortar 
and pestle in $25 \mathrm{~mL}$ of phosphate buffer $(0.2 \mathrm{M}, \mathrm{pH} 7.0)$ and centrifuged at 5,000 rpm for 30 minutes. The supernatant was then collected and measured. Proteins were quantified by the method of Bradford (1976) using the reagent Coomassie Blue G-250. Readings were taken in a spectrophotometer at $595 \mathrm{~nm}$ and compared with a reference curve obtained with known concentrations of bovine serum albumin (BSA). Three replicates of the extract were used, each one in triplicate, and the results were expressed in $\mathrm{mg} . \mathrm{g}^{-1}$ fresh weight.

Phenolic compounds - the seeds were ground in a cutting mill, and subsequently macerated with mortar and pestle in an acetone solution $(80 \%)$. The extract was centrifuged at 5,000 rpm for $30 \mathrm{~min}$ and diluted at 1:10. Four replicates of $1 \mathrm{~g}$ of seeds were used, and the methodology of Swain and Hillis (1959) was adapted for phenolic compound determination: for each test tube, $250 \mathrm{~L}$ of the sample were pipetted, $4 \mathrm{~mL}$ of distilled deionized water and $250 \mathrm{~L}$ of the Folin-Ciocalteu reagent $(0.25 \mathrm{~N})$ were added, stirred and allowed to stand for 3 minutes for the reaction to occur. Then, $500 \mu \mathrm{L}$ of sodium carbonate $(1 \mathrm{~N})$ were added, vortexed and incubated at $50{ }^{\circ} \mathrm{C}$ for 15 minutes in a water bath. The spectrophotometer was zeroed with the control (blank), and absorbance readings were made at a wavelength of $760 \mathrm{~nm}$. Three replicates of the extract were used, each in triplicate, and results were expressed in $\mathrm{mg} \cdot \mathrm{g}^{-1}$ fresh weight.

\section{Assessment of enzyme activity}

The extraction of peroxidases, catalases and polyphenol oxidases was performed according to Lee (1971): the seeds were left to soak for 12 hours and ground in a cutting mill and then macerated with mortar and pestle in a sodium phosphate buffer (100 mM, pH 7.0) with $10 \mathrm{mg}$ polyvinylpolypyrrolidone (PVPP), always cooled in an ice bath. The homogenate was centrifuged at $5,000 \mathrm{rpm}$ at $5{ }^{\circ} \mathrm{C}$ for 30 minutes. Three replicates of the extract were used, each in triplicate.

Peroxidase - peroxidase activity was determined using guaiacol $(13 \mathrm{mM})$ in sodium phosphate buffer $(50 \mathrm{mM}$, $\mathrm{pH}$ 6.0) as a donor of $\mathrm{H}+$ and $5 \mathrm{mM}$ hydrogen peroxide. The reaction was started by adding the enzyme extract containing $1 \mathrm{mg}$ of protein, incubated at $37^{\circ} \mathrm{C}$. The reading was performed at $470 \mathrm{~nm}$ (Lee, 1971) and the results were expressed as mg. $\mathrm{g}^{-1}$ fresh weight.

Catalase - determined according to the method of Goldblith and Proctor (1950). The enzyme extracts were incubated with $0.01 \mathrm{~N}$ hydrogen peroxide in $50 \mathrm{mM}$ phosphate buffer, $\mathrm{pH} 6.8$ at $25^{\circ} \mathrm{C}$. The reaction was stopped with sulfuric acid, and potassium permanganate $(\mathrm{KMnO} 4)$ was added at a final concentration of $0.005 \mathrm{~N}$. The reading was performed at $515 \mathrm{~nm}$, and results were expressed as micromol $\mathrm{H}_{2} \mathrm{O}_{2}$. min. $\mathrm{g}^{-1}$ fresh weight.

Polyphenol oxidase - determined according to the method of Campos et al. (2004). $3.6 \mathrm{~mL}$ of $50 \mathrm{mM}$ phosphate buffer, $\mathrm{pH} 6.0,1 \mathrm{~mL}$ of the enzyme extract, $0.1 \mathrm{~mL}$ of $0.1 \mathrm{M}$ catechol were placed in a cold tube, and the mixture was stirred for 15 seconds and then immediately incubated at $30{ }^{\circ} \mathrm{C}$ for 30 minutes. After this period, the tubes were transferred to an ice bath, and $0.2 \mathrm{~mL}$ of perchloric acid at $1.4 \%$ was added to the mixture. After stirring, the mixture was allowed to stand for 10 minutes, and the reading was immediately made at 395 $\mathrm{nm}$. The results were expressed as $\mathrm{mg} \cdot \mathrm{g}^{-1}$ fresh weight.

\section{Statistical Analyses}

The study used a completely randomized experimental design. Each treatment was a different storage time with four replications of 25 seeds each. Storage times were evaluated every six months for a period of 24 months and the control (freshly collected seeds) at time 0 , in a total of five treatments. Data underwent analysis of variance and, when it was significant, polynomial regression was applied for the chemical evaluations using the statistical software SISVAR (Ferreira, 2008).

The data obtained in the germination, emergence, seedling length and dry weight tests were submitted to the Kolmogorov-Smirnov test. For data that showed normality, ANOVA was performed and linear regression equations were obtained according to Levine et al. (2008). Furthermore, the data were subjected to correlation analysis by calculating Pearson's correlation coefficient (r) and testing their significance with the t-test (Zar, 2010). With the study of the correlation, the variables that had significant correlations at $5 \%$ probability were selected.

\section{Results and Discussion}

In the physiological quality tests, analysis of variance for germination, emergence, dry weight and seedling length of roots and shoots showed a significant effect for the storage periods, at $0.1 \%$ probability by the F-test.

The freshly collected T. roseoalba seeds showed 99\% germination, and after 24 months of storage, the value for germination dropped to $52 \%$ (Figure 1A), whereas the emergence percentage decreased from $88 \%$ (time 0 ) to $14 \%$ over 24 months' storage.

In general, the germination and all other response variables evaluated were reduced after six months' storage. The freshly collected seeds had higher performance compared with the stored seeds in all variables. Thus, it can be inferred that storage period influences germination, seedling length and seedling dry weight and especially emergence, where germination dropped significantly at 24 months' storage $(14.5 \%)$ (Figure 1A). Similar results were found by Oliveira 
et al. (2006), who found that $T$. aurea seeds have greater viability when freshly collected, with higher germination when sown on the surface and freshly collected.
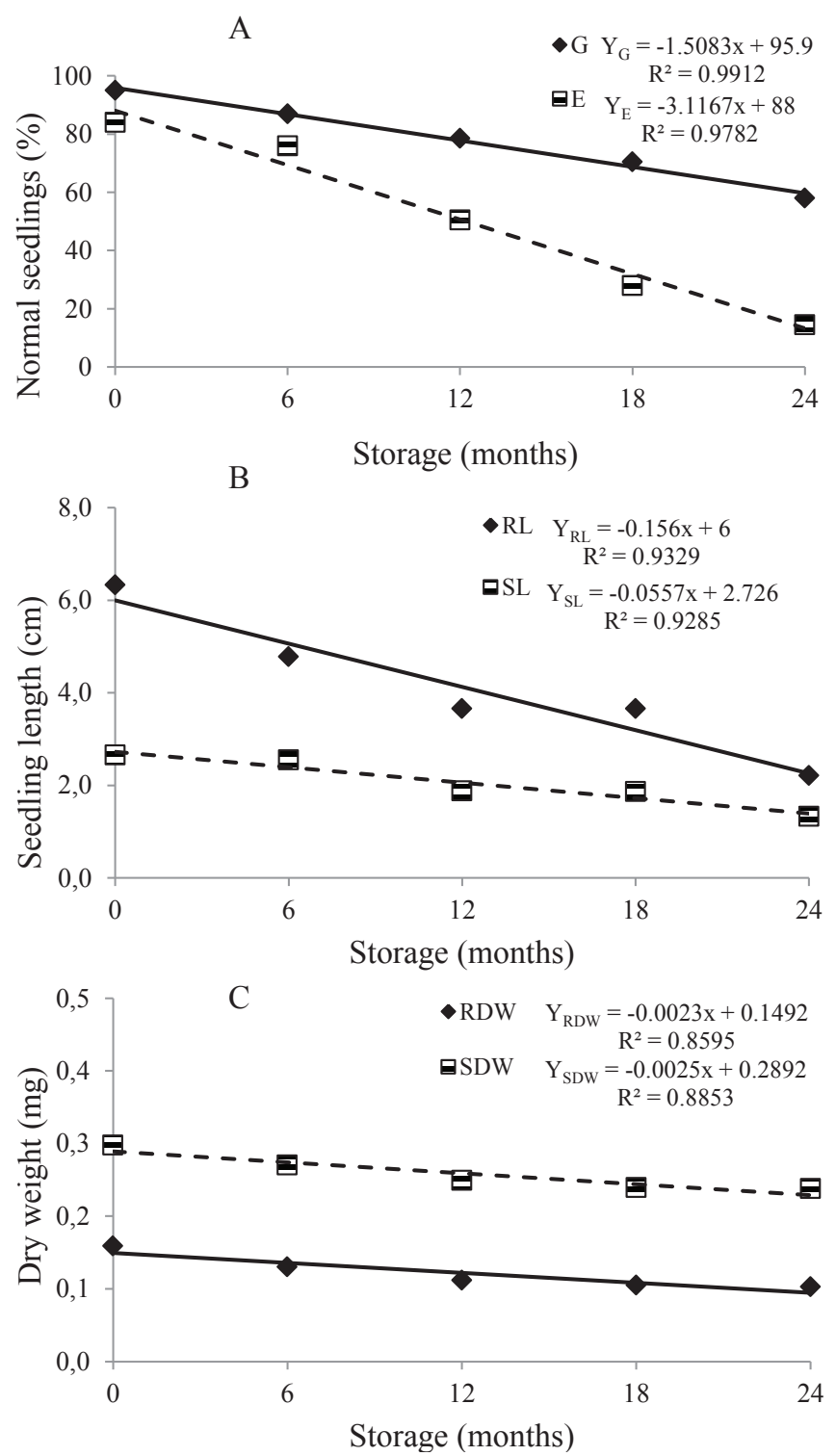

Figure 1. Percentage of normal seedlings (A), seedling length of roots and shoots (B) and root and shoot dry weight of seedlings (C), 30 days after germination of White ipe (Tabebuia roseoalba (Ridl.) Sandwith), under storage. (G - normal seedlings, E - Emergence; RL - root length, SL - shoot length, SDW - shoot dry weight; RDW - root dry weight).

High levels of lipids were observed (around 63\%) in the seeds of White ipe. Thus, they can be classified as oilseeds. In this experiment, during storage, seed lipid content was reduced. In the first six months, there was a small reduction in values, a decline of approximately $9 \%$, followed by a sharp reduction after 12 months of storage, i.e., 23\% (Figure 2A). A progressive reduction in lipid content was also found in Melanoxylon brauna seeds with advancing deterioration during storage, and increased lipid peroxidation, mediated by free radicals and peroxides, was one of the likely reasons for loss of seed viability during storage (Corte et al., 2010).
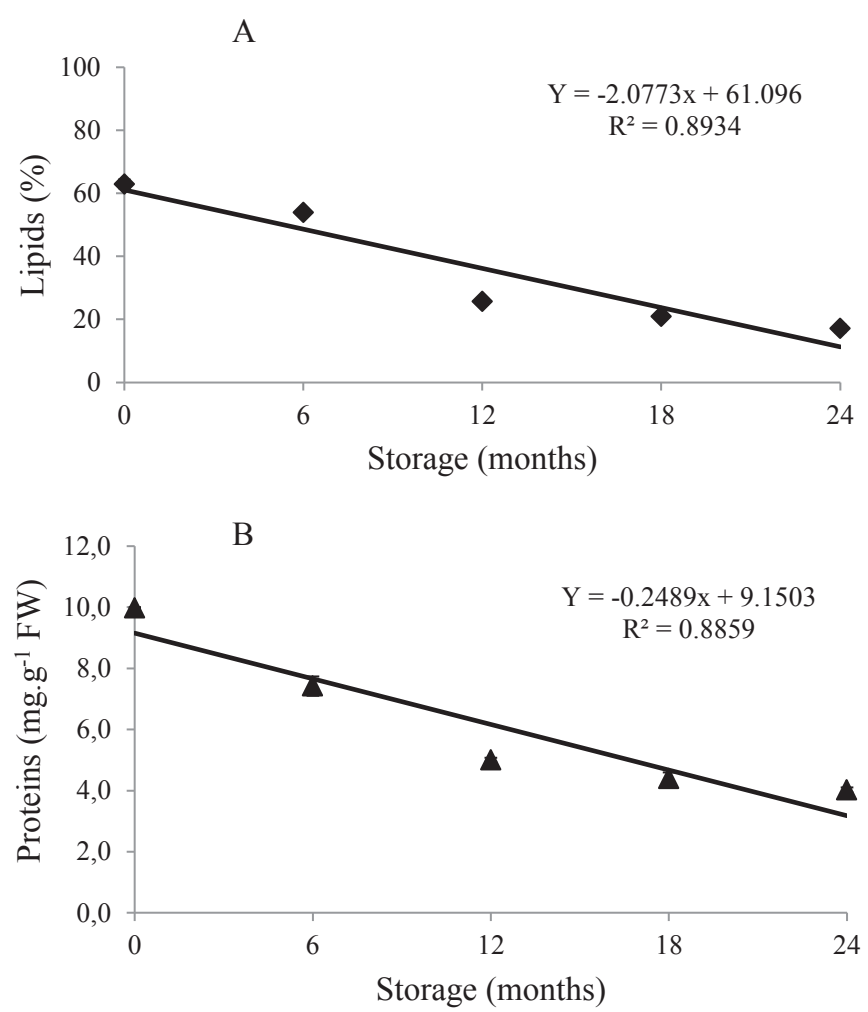

Figure 2. Lipid content (A) and protein content (B) at different storage times of White ipe seeds (Tabebuia roseoalba (Ridl.) Sandwith).

Protein content in White ipe seeds is low and there is a linear decrease in value throughout the storage period (Figure 2B). Ghasemnezhad and Honermeier (2007) also observed protein degradation during storage of sunflower seeds, which suggests that protein intake occurred with the release of amino acids for consumption on metabolic activity and respiration of the seeds. Changes in protein content were also associated with germination during storage of Handroanthus albus seeds, although further studies are still needed; thus, it can be inferred that reserve proteins may be associated with seed viability (Shibata et al., 2012).

The highest peroxidase activity in seeds can contribute to the preservation of physiological quality. However, the longer the storage period of White ipe seeds, the lesser peroxidase activity was observed, suggesting that the seeds are likely to be 
deteriorating (Figure 3A). Peroxidase plays a critical role in seed metabolism by using hydrogen peroxide as an acceptor, which may increase defense mechanisms and prevent loss of quality (Ushimaru et al., 2001). In stored cotton seeds, peroxidase activity decreased after storage (Vieira et al., 2008). The decline in peroxidase activity was also observed in Copaifera langsdorffii (Carvalho et al., 2006). In non-viable seeds, there is reduced activity of enzymes such as cytochrome oxidase, malate and alcohol dehydrogenase, succinic and glutamic dehydrogenase and catalase, which can contribute significantly to the reduction of respiratory activity (Desai et al., 1997).
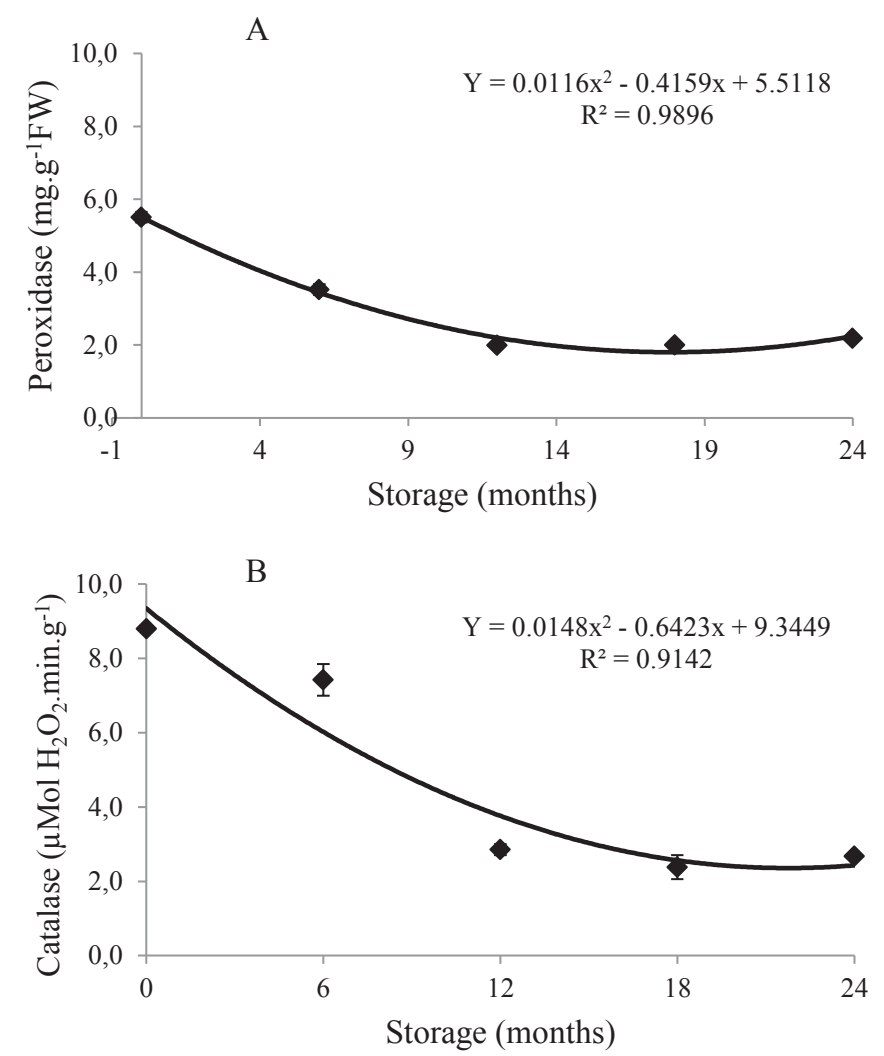

Figure 3. Peroxidase activity (A) and catalase activity (B) at different storage times of White ipe seeds (Tabebuia roseoalba (Ridl). Sandwith).

Catalase activity showed significant decrease during storage (Figure 3B). The activity was high at time zero, with significant decreases after six months. The stabilization of enzyme activity after 12 months of storage coincided with lipid content, whose decreased also stabilized after 12 months. These results corroborate the data reported by Corte et al. (2010), where catalase activity decreased and stabilized, coinciding with the stabilization of lipids in Melanoxylon brauna seeds under storage. In seeds of maize and beans, Muniz et al. (2007) found different banding patterns for catalase, which is indicative that the enzyme is associated with the decomposition of hydrogen peroxide in cells.

In Ginkgo biloba seeds stored at $4{ }^{\circ} \mathrm{C}$, catalase activity remained stable in the embryo and endosperm, and its activity was significantly reduced only at 12 months. However, when stored at $25{ }^{\circ} \mathrm{C}$, catalase activity was decreased at 6 month's storage (Tommasi et al., 2006). Reduction of catalase activity was also observed in onions during accelerated aging (Demirkaya et al., 2010).

Polyphenol oxidase activity and phenol levels of T. roseoalba seeds increased with storage time (Figure 4). The increased amount of phenolic compounds in seeds inhibits germination (Tokuhisa et al., 2007). Polyphenol oxidase is present in the plasma membrane of seeds, and when the membrane system is disrupted, the enzyme comes into contact with phenolic compounds by catalyzing their oxidation and reducing their content in seeds. Figure 5 shows a significant correlation between the variables and germination during storage (Figure 5). It can be inferred that any one of the variables has an important aspect to be considered for the storage period of the species, and the increase in phenolic compound content can be considered the variable most closely associated with loss of seed viability $(\mathrm{R}=0.83)$.
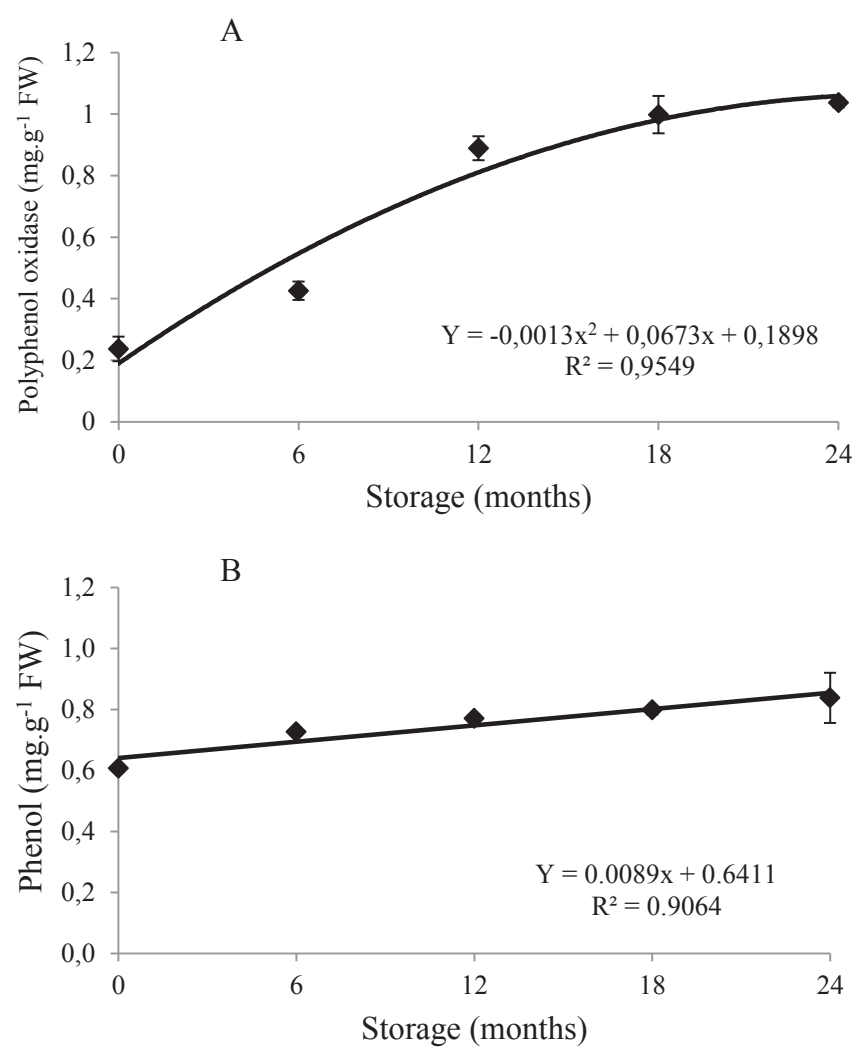

Figure 4. Polyphenol oxidase activity (A) and total phenol content (B) at different storage times of White ipe seeds (Tabebuia roseoalba (Ridl.) Sandwith). 
A
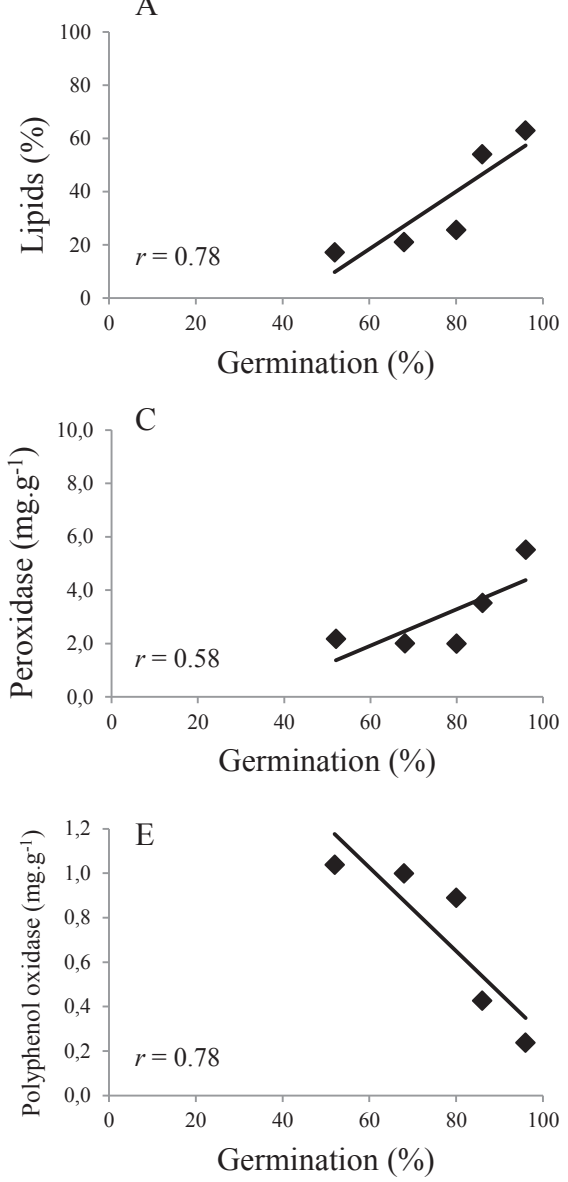

B

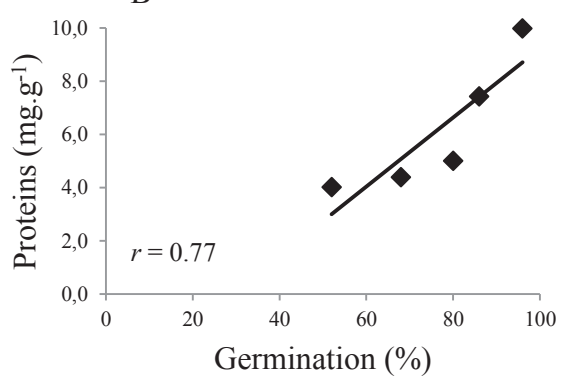

$\mathrm{D}$
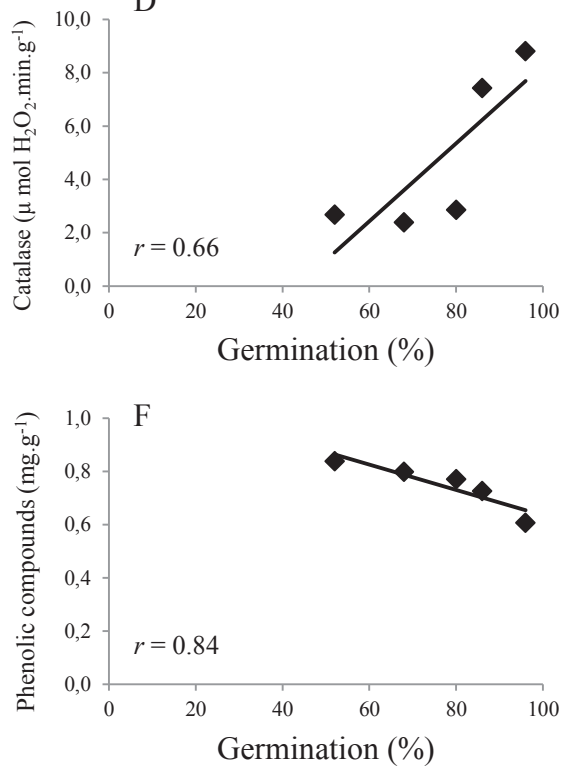

Figure 5. Linear correlation between the results of biochemical analysis and percentage of normal seedlings of Tabebuia roseoalba (Ridl.) Sandwith. (A - lipids, B - proteins, C - peroxidase, D - catalase; E - polyphenol oxidase, F - phenolic compounds).

With respect to longevity in storage, i.e. the period during which seed have viability is maintained, each species should be studied individually, and it may not be suitable to classify the behavior of seeds under storage simply based on family or genus, especially in the case of tropical forest species (Medeiros and Eira, 2006). Seeds of the genus Tabebuia are classified as orthodox (Roberts, 1973). However, the results of this study show that White ipe seeds (Tabebuia roseoalba) tolerate desiccation, but they do not withstand long storage periods, which may indicate a behavior that is rated as intermediary.

\section{Conclusions}

There is reduction in germination, seedling emergence and primary root length of T. roseoalba during storage for 24 months. This reduction is sharper for the latter two variables. During the storage of T. roseoalba seeds, there is a decrease in the content of lipids and proteins, and in peroxidase and catalase activity, and an increase of phenolic compounds and polyphenol oxidase activity.

Seeds should be stored and used within six months after harvest.

\section{References}

ABBADE, L. C.; PAIVA, P. D. O.; PAIVA, R. Germinação de sementes de ipê-branco em diferentes substratos e meios de cultura. Magistra, v. 22, n. 3,4 , p. $162-167,2010$. http://www.ufrb.edu.br/magistra/2000-atual/volume22-ano-2010/numero-3-e-4-jul-a-dez/445-germinacao-de-sementes-de-ipebranco-em-diferentes-substratos-e-meios-de-cultura-

ABBADE, L.C.; TAKAKI, M. Mobilisation of reserves during germination of seeds of Tabebuia roseoalba (Bignoniaceae). Seed Science and Technolology, v. 40, p. $259-264,2012$. http://www.ingentaconnect.com/content/ista/ sst/2012/00000040/00000002/art00011

ATAIIDE, G. M.; FLORES, A. V.; BORGES, E. E. L. Alterações fisiológicas e bioquímicas em sementes de Pterogyne nitens Tull. durante o envelhecimento artificial. Pesquisa Agropecuária Tropical, v. 42, n. 1, p. 71-76, 2012. http:// www.revistas.ufg.br/index.php/pat/article/download/16497/10439

BERJAK, P. Unifying perspectives of some mechanisms basic to desiccation tolerance across life forms. Seed Science Research, v.16, p.1-15, 2006. 
BLIGH, E. G.; DYER, W. J. A rapid method of total lipid extraction and purification. Canadian Journal Biochemistry Physiology, v. 37, n.8, p.911917, 1959.

BORBA FILHO, A. B.; PEREZ, S. C. J. G. A. Armazenamento de sementes de ipê-branco e ipê-roxo em diferentes embalagens e ambientes. Revista Brasileira de Sementes, v.31, n.1, p.259-269, 2009. http://www.scielo.br/ scielo.php?pid=S0101-31222009000100029\&script=sci arttext

BRADFORD, M.M. A rapid and sensitive method for the quantification of microgram quantities of proteins utilizing the principle of protein-dye binding. Analytical Biochemistry, v. 72, p. 248-254, 1976. http://www. sciencedirect.com/science/article/pii/0003269776905273

BRASIL. Ministério da Agricultura, Pecuária e Abastecimento. Regras para análise de sementes. Ministério da Agricultura, Pecuária e Abastecimento. Secretaria de Defesa Agropecuária. Brasília: MAPA/ACS, 2009. 395p. http:// www.bs.cca.ufsc.br/publicacoes/regras\%20analise\%20sementes.pdf

CAMPOS, A.D.; FERREIRA, A. G.; HAMPE, M. M. V.; ANTUNES, I. F.; BRANCÃO, N.; SILVEIRA, E. P.; OSÓRIO, V. A.; AUGUSTIN, E. Atividade de peroxidase e polifenoloxidase na resistência do feijão à antracnose. Pesquisa Agropecuária Brasileira, v. 39, n. 7, p.637-643, 2004. http://www. scielo.br/scielo.php?pid=S0100-204X2004000700004\&script=sci arttext

CARVALHO, L. R.; SILVA, E. A. A.; DAVIDE, A. C. Classificação de sementes florestais quanto ao comportamento no armazenamento. Revista Brasileira de Sementes, v.28, p.15-25, 2006. http://www.scielo.br/scielo. php?pid=S0101-31222006000200003\&script $=$ sci_arttext

CORTE, V. B.; BORGES, E. E. L. E.; LEITE, H. G.; PEREIRA, B. L. C.; GONÇALVES, J. F. C. Estudo enzimático da deterioração de sementes de Melanoxylon brauna submetidas ao envelhecimento natural e acelerado. Revista Brasileira de Sementes, v. 32, n. 1, p. 83-91, 2010. http://www.scielo. $\mathrm{br} /$ scielo.php?script=sci_arttextepid=S0101-31222010000100010elng=enetl ng=pt. $10.1590 / \mathrm{S} 0101-31222010000100010$

DELOUCHE, J.C.; BASKIN, C.C. Accelerated aging techniques for predicting the relative storability seed lots. Seed Science and Technology, v.1, n.2, p.427-252, 1973.

DEMIRKAYA, M.; DIETZ, K. J. H.; SIVRITEPE, Ö. Changes in antioxidant enzymes during ageing of onion seeds. Notulae Botanicae Horti Agrobotanici, v. 38 , n. 1, p. 49-52, 2010. http://www.notulaebotanicae.ro/index.php/nbha/ article/view/4575

DESAI, B.B.; KOTECHA, P.M.; SALUNKE, D.K. Seeds handbook: biology, production, processing and storage. New York: Marcel Dekker, 1997. 627p.

FERREIRA, D.F. SISVAR: um programa para análises e ensino de estatística. Revista Symposium, v.6, p.36-41, 2008.

GHASEMNEZHAD, A.; HONERMEIER, B. Influence of storage conditions on quality and viability of high and low oleic sunflower seeds. International Journal of Plant Production, v. 3, n.4, p. 38-48, 2007. http://journals.gau. ac.ir:8080/Jm/Programs/JurnalMgr/VolumArticle/EN_139 6.pdf

GREGGAINS, V.; FINCH-SAVAGE, W.E.; QUICK, W.P.; ATHERTON, N.M. Metabolism-induced free radical activity does not contribute significantly to loss of viability in moist-stored recalcitrant seeds of contrasting species. New Phytologist, v.148, p.267-276, 2000.

GOLDBLITH, S. A.; PROCTOR, B. E. Photometric determination of catalase activity. The Journal of Biological Chemistry, v.187, p.705-709, 1950.
GUEDES, R. S.; ALVES, E. U.; MELO, P. A. F. R.; MOURA, S. S. S.; SILVA, R. S. Storage of Tabebuia caraiba (Mart.) Bureau seeds in different packaging and temperatures. Revista Brasileira de Sementes, v. 34, n. 3, p. 433 - 440, 2012. http://www.scielo.br/scielo.php?script=sci arttext\&pid=S0101-31222012000300010

LEE, C. R. Influence of aluminum on plant growth and mineral nutrition of potatoes. Agronomy Journal,v.63,n.4,p.604-608, 1971.https://www.agronomy. org/publications/aj/abstracts/63/4/AJ0630040604?access=0\&view=pdf

LEHNER, A.; MAMADOU, N.; CÔME, D.; BAILLY, C.; CORBINEAU, F. Changes in soluble carbohydartes, lipid peroxidation and antioxidant enzyme activities in the embryo during agening in wheat grains. Journal Cereal Science, v. 47, p.555-565, 2008. http//:dx.doi.org/10.1016/j.jcs.2007.06.017

LEVINE, D.M.; STEPHAN, D.; KREBHIEL, T.C.; BERENSON, M.L. Estatística teoria e aplicações. Tradução de Teresa Cristina Padilha de Souza. Rio de Janeiro: LTC, 2008. 752 p.

LORENZI, H. Árvores Brasileiras. Manual de identificação e cultivo de plantas arbóreas do Brasil, v. 3. São Paulo: Instituto Plantarum, 2009. 384 p.

MEDEIROS, A. C. S; EIRA, M. T. S. Comportamento fisiológico, secagem e armazenamento de sementes florestais nativas. Embrapa Florestas, 2006. 13p. (Circular Técnica, 127). http://www.cnpf.embrapa.br/publica/circtec/ edicoes/circ-tec127.pdf

MUNIZ, F. R.; CARDOSO, M. G.; VON PINHO, E V. R.; VILELA, M. Qualidade fisiológica de sementes de milho, feijão, soja e alface na presença de extrato de tiririca. Revista Brasileira de Sementes, v. 29, n. 2, p. 195204, 2007. http://www.scielo.br/scielo.php?script=sci_arttext\&pid=S0101$1222007000200026 \& \operatorname{lng}=$ en\&nrm=iso

NAKAGAWA, J. Testes de vigor baseados no desempenho de plântulas. In: KRZYZANOWSKI, F.C.; VIEIRA, R.D.; FRANÇA-NETO, J.B. (Ed.). Vigor de sementes: conceitos e testes. Londrina: ABRATES, 1999. p.2.1-2.21.

NASCIMENTO, W. M. O.; CICERO, S. M.; NOVEMBRE, A. D. L. C. Conservação de sementes de açaí (Euterpe oleracea Mart.). Revista Brasileira de Sementes, v. 32, n. 1, p. 24-33, 2010. http://www.scielo.br/ scielo.php?script=sci_arttext\&pid=S0101-31222010000100003\&lng=en\&tl ng $=$ pt. $10.1590 / \mathrm{S} 0101-31222010000100003$

OLIVEIRA, A. K. M.; SCHLEDER, E. D.; FAVERO, S. Caracterização morfológica, viabilidade e vigor de sementes de Tabebuia aurea (Silva Manso) Benth. \& Hook. f. ex. S. Moore. Revista Árvore, v. 30, n. 1, p. 2532, 2006. http://www.scielo.br/scielo.php?script=sci_arttext\&pid=S0100$67622006000100004 \& \operatorname{lng}=$ en\&nrm=iso

POTT, A.; POTT, V.J. Plantas do Pantanal. Brasília, Embrapa, 1994. 320p.

ROBERTS, E.H. Predicting the storage life of seeds. Seed Science and Technology, v.1, n.3, p.499-514, 1973.

SANTOS, C. M. R.; MENEZES, N. L.; VILLELA, F. A. Modificações fisiológicas e bioquímicas em sementes de feijão no armazenamento. Revista Brasileira de Sementes, v. 27, n. 1, p. 104-114, 2005. http://www.scielo.br/scielo. php?script=sci_arttext\&pid=S0101-31222005000100013\&lng=en\&nrm=iso

SHIBATA, M.; COELHO, C. M. M.; OLIVEIRA, L. M.; GARCIA, C. Accelerated aging of ipê seeds under controlled conditions of storage. Revista Brasileira de Sementes, v. 34, n. 2, p. 247-254, 2012. http://www.scielo.br/scielo. php?script=sci_arttext\&pid=S0101-31222012000200009\&lng=en\&nrm=iso 
STOCKMAN, A. L.; BRANCALION, P. H. S.; NOVEMBRE, A. D. L. C.; CHAMMA, H. M. C. P. Sementes de ipê-branco (Tabebuia roseoalba (Ridl.) Sand. - Bignoniaceae): temperatura e substrato para o teste de germinação. Revista Brasileira de Sementes, v.29, n.3, p.121-125, 2007. http://www. scielo.br/scielo.php?script=sci_arttext\&pid=S0101-31222007000300016

SWAIN, T.; HILLIS, W. T. The phenolic constituents of Prunnus domestica. Journal of the Science of Food and Agriculture, v.10, p.135-144, 1959. http:// onlinelibrary.wiley.com/doi/10.1002/jsfa.2740100211/abstract

TAVEIRA, J. H. S.; ROSA, S. D. V. F.; BORÉM, F. M.; GIOMO, G. S.; SAATH, R. Perfis proteicos e desempenho fisiológico de sementes de café submetidas a diferentes métodos de processamento e secagem. Pesquisa Agropecuária Brasileira, v.47, n.10, p.1511-1517, 2012. http://www.scielo. br/scielo.php?script=sci_arttext\&pid=S0100-204X2012001000014\&lng=en $\& t \operatorname{lng}=$ pt. $10.1590 /$ S0100-204X2012001000014

TOKUHISA, D.; DIAS, D. C. F. S.; ALVARENGA, E. M.; DIAS, L. M.; DAVID, L. S. Tratamentos para superação da dormência em sementes de mamão. Revista Brasileira de Sementes, v. 29, n. 1, p. 131-139, 2007. http://www.scielo.br/scielo. php?pid=S0101-31222007000100018\&script=sci_abstract
TOMMASI, F.; PACIOLLA, C.; PINTO, M.C.; GARA, L.D. Effects of storage temperature on viability, germination and antioxidant metabolism in Ginkgo biloba L. seeds. Plant Physiology and Biochemistry, v.44, p.359-368, 2006. http://www.ncbi.nlm.nih.gov/pubmed/16889978

USHIMARU, T.; KANEMATSU, S.; KATAYAMA, M.; TSUJI, H. Antioxicidative enzymes in seedling of Nelumbo nucifera germinated under water. Physiologia Plantarum, v.112, n.1, p.39-46, 2001. http://www.ncbi. nlm.nih.gov/pubmed/11319013

VIEIRA, R. M.; BELTRÃO, N. E. M.; LIMA, R. L. S.; LEÃO, A. B. O Produção de sementes de algodoeiro. In: BELTRÃO, N. E. M.; AZEVEDO, D. M. P., 2. ed. O agronegócio do algodão no Brasil. Brasília, DF: Embrapa Informação Tecnológica, 2008. p.509-533.

ZAR, J.H. Biostatistical analysis. 5ed. Upper Saddle River: Prentice-Hall, 2010. 994p. 